\title{
PENGARUH DOSIS KOMPOS LIMBAH KULIT KOPI DAN FUNGI MIKORIZA ARBUSKULAR TERHADAP HASIL TANAMAN MELON (Cucumis melo L.)
}

\section{THE EFFECT OF COMPOSTE USE OF WASTE COFFEE SKIN AND ARBUSCULAR MICORIZA FUNCTION ON PRODUCTION OF MELON (Cucumis melo L.)}

\author{
Mohammad Ebigail ${ }^{1}$, Nanda Mayani², Erita Hayati* ${ }^{*}$ \\ ${ }^{1}$ Mahasiswa Jurusan Agroteknologi, Fakultas Pertanian, Universitas Syiah Kuala \\ ${ }^{2}$ Staf Dosen Jurusan Agroteknologi, Fakultas Pertanian, Universitas Syiah Kuala \\ Jl. Tgk. Hasan Krueng Kalee No.2, Kopelma Darussalam, Syiah Kuala, Kota Banda Aceh 23111 \\ Email: mebigailsangfenomenal@gmail.com
}

\begin{abstract}
ABSTRAK
Penelitian ini bertujuan untuk menguji dosis kompos limbah kulit kopi dan mikoriza serta interaksi diantara keduanya yang paling efektif untuk meningkatkan produksi tanaman melon yang menggunakan menggunakan Rancangan Acak Kelompok (RAK) Faktorial dengan 2 faktor perlakuan yaitu : Faktor I Dosis kompos limbah kulit buah kopi (K) K0 $=0 \mathrm{~g}$ polibag $^{-1}, \mathrm{~K}_{1}=188 \mathrm{~g}$ polibag $^{-1}, \mathrm{~K}_{2}=376 \mathrm{~g}$ polibag $^{-1}$ dan $_{3}=564 \mathrm{~g} \mathrm{polibag}^{-1}$ Faktor II : Dosis mikoroza (M) $\mathrm{M}_{0}=0 \mathrm{~g}$ polibag-1, $\mathrm{M}_{1}=10 \mathrm{~g} \mathrm{polibag}^{-1}, \mathrm{M}_{2}=15 \mathrm{~g}_{\text {polibag }}{ }^{-1}$ dan $\mathrm{M}_{3}=20 \mathrm{~g}$ polibag $^{-1}$. Hasil penelitian menunjukan penggunaan dari kompos limbah limbah kulit buah kopi berpengaruh sangat nyata. terhadap diameter buah dan berpengaruh nyata terhadap berat buah, dosis kompos terbaik dijumpai pada perlakuan $\mathrm{K}_{2}$ (376 $\left.\mathrm{g}_{\text {polibag }}{ }^{-1}\right)$. Terdapat interaksi sangat nyata akibat penggunaan kompos limbah kulit buah kopi dan fungi mikoriza terahadap diameter buah dan berat buah, interaksi terbaik dijumpai pada perlakuan $\mathrm{K}_{3} \mathrm{M}_{2}\left(564 \mathrm{~g}_{\text {polibag }}{ }^{-1}\right.$ dan $\left.15 \mathrm{~g}_{\text {polibag }}{ }^{-1}\right)$.
\end{abstract}

Kata kunci: produksi, melon, kompos limbah kulit kopi, mikoriza arbuskular

\section{ABSTRAK}

This study aims to examine the dosage of coffee skin waste compost and mycorrhiza and the interactions between the two of the most effective ways to increase melon production using Factorial Randomized Block Design (RBD) with 2 treatment factors, namely: Factor I dose of coffee fruit skin waste compost (K) $\mathrm{K}_{0}=0 \mathrm{~g}$ polybag $^{-1}, \mathrm{~K}_{1}=188 \mathrm{~g} \mathrm{polybag}^{-1}, \mathrm{~K}_{2}=376 \mathrm{~g} \mathrm{polybag}^{-1}$ and $\mathrm{K}_{3}=564 \mathrm{~g} \mathrm{polybag}^{-1}$ Factor II: Dosage of mycorrhiza (M) M0 $=0$ g polybag $^{-1}, \mathrm{M}_{1}=10 \mathrm{~g}$ polybag $^{-1}, \mathrm{M}_{2}=15 \mathrm{~g}$ polybag $^{-1}$ and $_{3}=20 \mathrm{~g}$ polybag $^{-1}$. The results showed that the use of compost of coffee fruit peel waste had a very significant effect. on fruit diameter and significantly affected fruit weight, the best compost dose was found in $\mathrm{K}_{2}$ treatment $\left(376 \mathrm{~g} \mathrm{polybag}^{-1}\right)$. There was a very real interaction due to the use of coffee fruit skin waste compost and mycorrhiza fungi on fruit diameter and fruit weight, the best interactions were found in $\mathrm{K}_{3} \mathrm{M}_{2}$ treatment $\left(564 \mathrm{~g} \mathrm{polybag}^{-1}\right.$ and $15 \mathrm{~g} \mathrm{polybag}^{-1}$ ).

Keywords: production, melon, coffee skin waste compost, arbuscular mycorrhiza.

\section{PENDAHULUAN}

Melon (Cucumis melo L.) ialah tanaman buahan semusim yang bernilai kormersial tinggi dan pangsa pasar yang lebar serta beragam, mulai dari pasar tradisional hingga pasar modern, restoran dan hotel. Hal ini berarti melon memiliki prospek yang baik untuk diusahakan, karena memiliki nilai ekonomi yang sangat baik dibandingkan komoditas buah yang lain. Harga buah yang membumbung tinggi juga menjadi alasan bagi petani untuk mengusahakan komoditas agribisnis ini secara intensif dan menjadikan melon sebagai komoditas unggulan (Arfah et al., 2016)

Hasil survei Badan Pusat Statistik Indonesia (2016), pada tahun 2012 produksi melon sebanyak 125.447 ton dan pada tahun 2013 menurun menjadi 125.207 ton namun pada tahun 2014 meningkat sebesar 150.347 ton dan mengalami penurunan kembali 137.879 ton pada 
tahun 2015 dan 117.337 ton pada tahun 2016. Penanaman melon terus meluas ke berbagai daerah termasuk pulau Sumatera diantaranya provinsi Sumatera Utara dan provinsi Aceh karena memiliki iklim yang sesuai untuk daerah pembudidayaan melon. Hasil survei Badan Pusat Statistik Aceh (2012), tanaman melon telah dibudidayakan di beberapa kabupaten atau kota di provinsi Aceh. Pertumbuhan dan perkembangan tanaman melon juga dipengaruhi oleh ketersediaan unsur hara. Unsur hara dapat ditingkatkan ketersediannya dengan memberikan pupuk kompos yang berfungsi sebagai penyedia unsur hara organik bagi tanaman, memperbaiki struktur tanah dan dapat menahan air dalam tanah (Sunardjono, 2005). Menurut Sudiarto dan Gusmaini (2004) bahan organik seperti limbah kulit kopi, tandan kosong kelapa sawit dan jerami padi cukup melimpah dan kurang dimanfaatkan. Berdasarkan hal tersebut, maka limbah kulit kopi sangat berpotensi diolah menjadi pupuk organik.

Kopi merupakan salah satu tanaman yang menghasilkan limbah sampingan yang cukup besar dari hasil pengolahan. Sekitar 50-60 \% merupakan limbah kulit kopi dari hasil panen. Jika $1000 \mathrm{~kg}$ kopi segar berkulit, maka biji kopi yang diperoleh sekitar 400-500 kg, dan selebihnya merupakan kulit kopi. Petani belum memanfaatkan limbah kopi secara optimal. Padahal kulit kopi bisa digunakan sebagai bahan utama dalam pembuatan pupuk (Puslitkoka, 2005).

Berlian et al. (2015) telah membuktikan bahwa dengan penambahan kompos kulit kopi dengan dosis $30 \mathrm{~g}, 60 \mathrm{~g}$ dan $90 \mathrm{~g}$, dari dosis yang dipakai bahwa dosis $90 \mathrm{~g}$ yang lebih optimal dalam hal menumbuhkan dan mengembangkan tanaman cabai keriting (Capsicum annum L.) secara signifikan. Penelitian lain yang dilakukan oleh Valentiah et al. (2015) tentang kompos kulit kopi untuk peningkatan hasil produksi berat segar pada tanaman brokoli (Brassica oleracea), dikarenakan penyerapan unsur hara fosfor dalam tanah sangat efektif. Sama halnya dengan budi daya tanaman lain, pemupukan merupakan hal penting dalam budi daya melon. Pemberian pupuk diawali dengan pupuk dasar serta dilanjutkan dengan pemberian pupuk susulan. Pupuk dasar yang biasa digunakan pada budi daya melon yaitu kompos serta pupuk NPK, sedangkan pupuk susulan yang biasa digunakan adalah pupuk Nitrogen, pospor dan kalium dan pupuk KNO3 dengan frekuensi pemberian setiap sepuluh hari sampai 2 atau 3 minggu sebelum masa panen. Pupuk anorganik yang terlalu sering digunakan menyebabkan penurunan mikroba tanah yang bermanfaat dalam meningkatkan kesuburan tanah. Salah satu mikroba tanah yang dapat meningkatkan kesuburan tanaman dan meningkatkan produksi tanaman yaitu fungi mikoriza arbuskula (FMA) (Tetelepta, 2014)

Pemanfaatan FMA dapat mendorong tanaman untuk menyerap berbagai hara. hara $\mathrm{P}$ (fosfor) merupakan hara yang paling utama diserap pada kondisi $\mathrm{P}$ rendah untuk membantu pertumbuhan tanaman, serta menguatkan dari keadaan yang ekstream (Jeffries et al. 2003; Porras-Soriano et al. 2009; Cruz et al. 2014). Tanaman melon juga dapat membentuk simbiosis dengan FMA (Srivastava et al. 2012). FMA berperan mencegah cekaman kekeringan bagi tanaman melon dan mereduksi fungi patogen, seperti Fusarium (Huang et al, 2011; Martínez et al,. 2011). Pertumbuhan tanaman melon dapat ditingkatkan secara bersamaan dengan cara Inokulasi CMA dan Azospirillum sp.. Inokulasi CMA dapat meninggikan tanaman, memanjangkan akar, menambah jumlah pada akar lateral, bobot basah, bobot kering, jumlah daun dan luas total pada daun, serta meningkatkan kandungan nitrogen, fosfor, dan karbon daun melon, namun inokulasi pada Azospirilium sp. membantu pertumbuhan akar tanaman melon (Tatelepta, 2014). FMA dapat menambah tinggi tanaman, banyaknya daun, luas daun, diameter batang, bobot basah dan kering tajuk, panjang akar, bobot basah dan kering akar (Dasgan et al., 2008). Menurut Penjelasan diatas, maka perlu dilakukan penelitian kompos limbah kulit kopi dan FMA terhadap tanaman melon

Pengaruh Dosis Kompos Limbah Kulit Kopi Dan Fungi Mikoriza Arbuskular Terhadap Hasil Tanaman Melon (Cucumis melo L) Mohammad Ebigail, EritaHayati, Nanda Mayani) Jurnal Ilmiah Mahasiswa Pertanian Unsyiah, Vol. 4, No. 2, Mei 2019: 101-110 


\section{METODE PENELITIAN}

penelitian ini telah dilaksanakan di Kebun Percobaan Fakultas Pertanian Universitas Syiah Kuala Banda Aceh. Penelitian ini telah dilaksanakan pada Desember 2018 sampai dengan Maret 2018.

Bahan yang akan digunakan pada penelitian ini adalah benih melon varietas Orange Meta, alkohol, aquades dan mikoriza (Glomus sp.) $180 \mathrm{~g}$, limbah kulit kopi kering (13 kg), yang diperoleh dari Kabupaten Bener Meriah Kecamatan Pintu Rime Gayo Desa Simpang Lancang, dedak (1,3 kg), EM4 (350 ml), gula pasir (6 sendok makan), air (13 L), polybag ukuran $(37 \mathrm{x} 40 \mathrm{~cm})$, tanah, polibag $(10 \mathrm{~kg})$, ajir $(2$ meter) dan polibag ukuran $(8 \mathrm{X} 9 \mathrm{~cm})$ untuk pembibitan. Alat yang telah digunakan pada penelitian ini adalah cangkul, terpal, gembor, meteran, ember, jangka sorong, timbangan, kuas, cat putih, buku, alat tulis, kamera, karung dan cawan petri.

Penilitan ini menggunakan Rancangan Acak Kelompok (RAK) faktorial dengan 2 faktor perlakuan faktor pertama adalah dosis kompos limbah kulit kopi (K) dan faktor kedua adalah dosis mikoriza (M) yang masing-masing terdiri dari 4 taraf. Banyak ulangan yang dilakukan untuk setiap perlakuan yaitu sebanyak 3 kali ulangan. Setiap unit perlakuan terdiri dari 4 tanaman. Dengan demikian jumlah seluruhnya yaitu 48 unit tanaman sampel.

Menurut Wijayanti (2014), kompos yang dibuat dari limbah kulit kopi memiliki beberapa tahapan, yaitu pengeringan limbah kulit kopi, kemudian dicacah menjadi ukuran yang lebih kecil untuk memudahkan proses dekomposisi. Sebanyak 13 kilogram kulit kopi dicampurkan dengan dedak sebanyak $1,3 \mathrm{~kg}$, kemudian diaduk hingga merata. Kemudian 350 ml larutan EM-4 dan 6 sendok makan gula pasir dilarutkan kedalam 13 ltr air. Setelah itu Larutan tersebut disiram pada limbah kulit kopi yang ditumpuk secara merata sampai bahan terasa lembab.

Tumpukan limbah diaduk kembali supaya larutan dan limbah dapat bercampur dengan baik dan merata. Cukupnya kadar air yang terkandung ditandai dengan tidak menetesnya air ketika digenggam dan mekar ketika genggaman dilepaskan. Tumpukan tersebut dimasukkan ke dalam karung kemudian karung tersbut dilubangi untuk aerasi selama proses pengomposan. Karung disimpan pada tempat kering dan terbebas dari hujan serta sinar matahari langsung dengan suhu dipertahankan berkisar $40-50^{\circ} \mathrm{C}$. Jika suhu kompos di dalam karung hangat, itu berarti menandakan sedang berlangsungnya proses fermentasi. Ciri-ciri kompos yang telah jadi yaitu memiliki wrn yang hitam, gembur, tidak panas serta tidak berbau.

Media penanaman bibit yang telah digunakan yaitu tanah top soil yang berasal dari Kebun Percobaan Fakultas Pertanian Universitas Syiah Kuala di campur dengan pupuk kandang dengan perbandingan 1:1 yang sebelumnya sudah diayak terlebih dahulu. Kemudian campuran media dimasukkan ke dalam polibag ukuran $(8 \times 9 \mathrm{~cm})$.

Benih melon yang telah digunakan terlebih dahulu, benih disterilkan menggunakan alcohol 70\% dengan durasi 5 menit lalu dibilas hingga bersih menggunakan aquades dengan 4 kali ulangan dan disimpan didalam cawan petri yang telah dilapisi dengan kertas yang sudah di lembabkan terlebih dahulu selama 20 jam.

. Setelah itu, benih melon ditanam pada media pembibitan (Huang et al. 2011).

Benih melon yang telah digunakan, disterilkan terlebih dahulu menggunakan alkohol $70 \%$ dengan waktu 5 menit. Setelah itu dibersihkan dengan aquades sebanyak 4 kali dan diperam selama 20 jam pada cawan petri yang dilapisi kertas saring lembab. Kemudian benih yang sudah siap ditanaman kan dalam media pembibitan (Huang et al. 2011).

Pengaruh Dosis Kompos Limbah Kulit Kopi Dan Fungi Mikoriza Arbuskular Terhadap Hasil Tanaman Melon (Cucumis melo L) Mohammad Ebigail, EritaHayati, Nanda Mayani) Jurnal Ilmiah Mahasiswa Pertanian Unsyiah, Vol. 4, No. 2, Mei 2019: 101-110 
Media penanaman yang telah digunakan yaitu tanah top soil diambil dari Kebun Percobaan Fakultas Pertanian Universitas Syiah Kuala yang sudah diayak kemudian dimasukkan ke dalam polibag ukuran 25 liter. Kemudian pupuk kompos limbah kulit kopi dicampurkan ke dalam polibag sesuai dengan dosis perlakuan.

Pemasangan ajir telah dilakukan sebelum pelaksanaan penanaman bibit melon. Ajir ditanam diluar polibag dengan panjang $2 \mathrm{~m}$, tanaman melon merambat ke atas sehingga menghasilkan buah yang lebih baik.

Penanaman bibit melon telah dilakukan saat bibit melon yang sudah berumur 14 hari setelah semai. Pemindahan bibit melon dilakukan pada sore hari dengan cara polybag yang digunakan sebagai wadah media bibit melon dirobek sisi sampingnya dengan menggunakan pisau silet dengan hati-hati agar media pembibitan tidak hancur. Bibit dipindahkan ke media penanaman bersama dengan media pembibitan. Kemudian disiram hingga kapasitas lapang.

Pemberian FMA telah dilakukan bersamaan pada saat bibit dipindah tanam, yaitu diberikan didalam lubang tanam lalu ditutup dengan permukaan tanah secara bersamaan dengan bibit melon yang baru dipindahkan. pemberian FMA diberikan sesuai dosis perlakuan pada setiap percobaan tanaman melon.

Pemupukan telah dilakukan dengan menggunakan pupuk NPK mutiara sebanyak $5 \mathrm{~g}$ NPK 16:16:16 per polibag pada awal penanaman dan satu kali pada setiap pengamatan 7,14 , 21, 28 dan 35 HST.

Pemeliharaan tanaman yang dilakukan meliputi Penyiraman yang telah dilakukan 2 kali sehari pada saat pagi dan sore hari dan disesuaikan dengan keadaan dilapangan.

Lalu Pemangkasan pada tanaman melon telah dilakukan pada cabang pertama hingga cabang kedelapan. Dilakukan pemeriharaan pada cabang kesembilan sampai cabang ketiga belas sebagai tempat pembuahan dan tunas pucuk yang terus tumbuh diatas cabang ketujuh belas harus dipangkas. Setelah terjadi pembuahan, disisakan satu bakal buah yang terbaik dan selebihnya dipangkas.

Serta pengendalian hama dan penyakit telah dilakukan pengamatan rutin terhadap gangguan hama dan penyakit dengan melihat gejala dan tanda kerusakan yang muncul. Pengendalian secara kultur teknis dan mekanis menjadi pilihan yang pertama yang dilakukan dan jika gangguan hama dan penyakit tidak dapat dikendalikan lagi maka dilakukan pengendalian secara kimiawi.

Pemanenan telah dilakukan ketika buah berumur 70 HST. Kriteria pemanenan yaitu keretakan pada kulit melon dan mengeluarkan aroma harum melon dipanen pada sore hari pukul 16:00 wib. Cara memanen melon dengan memegang ujung buah melon lalu dipotong, cabang pada buah digunting dengan ukuran minimal $2 \mathrm{~cm}$ dari pangkal tangkai guna memperpanjang kemampuan penyimpanan buah

\section{HASIL DAN PEMBAHASAN}

\subsection{Pengaruh Kompos limbah Kulit kopi Terhadap hasil tanaman Melon}

Hasil pada uji $\mathrm{F}$ analisis ragam menunjukkan bahwasanya pemberian kompos limbah kulit kopi berpengaruh sangat nyata terhadap diameter buah dan berpengaruh nyata pada berat buah. Rata-rata diameter buah, berat buah dan infeksi akar tanaman melon akibat pemberian kompos limbah kulit kopi dapat dilihat pada Tabel 1. 
Tabel 1. Rata-rata diameter buah, berat buah dan infeksi akar tanaman melon akibat pemberian kompos limbah kulit kopi

\begin{tabular}{cccc}
\hline Dosis Kompos $\left(\mathrm{g} \mathrm{polibag}^{-1}\right)$ & Diameter Buah $(\mathrm{Cm})$ & Berat Buah $(\mathrm{kg})$ & Infeksi akar $(\%)$ \\
\hline $\mathrm{K}_{0}(0)$ & $12,45 \mathrm{a}$ & $0,91 \mathrm{a}$ & $31,08 \mathrm{a}$ \\
$\mathrm{K}_{1}(188)$ & $13,59 \mathrm{bc}$ & $0,96 \mathrm{a}$ & $57.00 \mathrm{bc}$ \\
$\mathrm{K}_{2}(376)$ & $13,73 \mathrm{c}$ & $1,21 \mathrm{~b}$ & $52,83 \mathrm{~b}$ \\
$\mathrm{~K}_{3}(564)$ & $13,22 \mathrm{~b}$ & $1,01 \mathrm{a}$ & $59,75 \mathrm{c}$ \\
\hline BNT $0.05 \%$ & 0,43 & 0.21 & 6,82 \\
\hline
\end{tabular}

Keterangan : Angka yang diikuti oleh huruf yang sama pada kolom yang sama berbeda tidak nyata pada taraf peluang $5 \%\left(\mathrm{BNT}_{0,05}\right)$.

Tabel 1 menujukkan bahwa, pemberian kompos limbah kulit kopi terhadap diameter buah melon dengan perlakuan terbaik dijumpai pada dosis $\mathrm{K}_{2}\left(376 \mathrm{~g}\right.$ polibag $\left.{ }^{-1}\right)$ yang berbeda nyata dengan dosis $\mathrm{K}_{0}\left(0 \mathrm{~g}_{\text {polibag }}{ }^{-1}\right)$, namun berbeda tidak nyata pada dosis $\mathrm{K}_{1}(188 \mathrm{~g}$ polibag $\left.^{-1}\right)$ dan $\mathrm{K}_{3}\left(564 \mathrm{~g}\right.$ polibag $\left.{ }^{-1}\right)$, sedangkan diameter terendah dijumpai pada dosis $\mathrm{K}_{0}(0 \mathrm{~g}$ polibag $\left.^{-1}\right)$. Pemberian kompos limbah kulit kopi terhadap berat buah melon terbaik dijumpai pada dosis $\mathrm{K}_{2}\left(376 \mathrm{~g}_{\text {polibag }}{ }^{-1}\right)$ yang berbeda nyata pada dosis $\mathrm{K}_{0}\left(0 \mathrm{~g}\right.$ polibag $\left.^{-1}\right), \mathrm{K}_{1}(188 \mathrm{~g}$ polibag $\left.^{-1}\right)$ dan $\mathrm{K}_{3}\left(564 \mathrm{~g}\right.$ polibag $\left.^{-1}\right)$ dosis $\mathrm{K}_{0}\left(0 \mathrm{~g} \mathrm{polibag}^{-1}\right)$ sedangkan berat buah terendah cenderung dijumpai pada perlakuan $\mathrm{K}_{0}\left(0 \mathrm{~g}\right.$ polibag $\left.^{-1}\right)$. Rata-rata infeksi akar akibat pemberian kompos limbah kulit kopi terbaik dijumpai pada perlakuan $\mathrm{K}_{3}\left(564 \mathrm{~g}^{-1}\right.$ polibag $\left.{ }^{-1}\right)$ yang berdeda nyata dengan perlakuan $\mathrm{K}_{0}\left(0 \mathrm{~g}\right.$ polibag $\left.^{-1}\right)$ dan $\mathrm{K}_{2}\left(376 \mathrm{~g}\right.$ polibag $\left.{ }^{-1}\right)$ namun tidak berbeda nyata dengan $\mathrm{K}_{1}\left(188 \mathrm{~g}\right.$ polibag $\left.^{-1}\right)$ sedangkan infeksi akar terendah dijumpai pada dosis $\mathrm{K}_{0}(0$ $\mathrm{g} \mathrm{polibag}^{-1}$ ).

Hasil pada penelitian ini menunjukkan bahwaasanya perlakuan pada kompos kulit kopi dan mikoriza berpengaruh sangat nyata terhadap diameter buah dan berat buah dengan perlakuan terbaik ditunjukan pada $\mathrm{K}_{2}\left(376 \mathrm{~g}_{\text {polibag }}{ }^{-1}\right)$ hal ini dikarenakan pemberian kompos dapat memperbaiki sifat pada kimia dan fisik tanah dan juga sebagai penyedia unsur hara yang lengkap sehingga pertumbuhan sereta produksi tanaman lebih baik hal ini sesuai dengan La Ode Safuan dan Andi Bahrun (2012) menyatakan bahwa pemberian bahan organik pada tanaman melon akan memberikan hasil dan kualitas yang lebih baik.

Roesmarkan dan yuwono (2002) menuliskan bahwasanya dalam proses mineralisasi bahan organik akan melepaskan unsur yang dibutuhkan tanaman kedalam tanah sehingga dapat mengoptimalkan pertumbuhan dan hasil dengan baik. Pada berat buah diduga karena pemberian unsur hara yang sesuai dapat membuat tanaman menjadi sehat sehingga tanaman mampu berbuah secara baik hal ini sesuai dengan pernyaatan Dwidjoseputro (1983) tanaman akan tumbuh dengan subur apabila ia mendapatkan segala hara yang dibutuhkan tersedia dengan kesusuaian yang dibutuhkan tanaman. Hal ini ditambahkan oleh Hayati et al (2012) pertumbuhan pada tanaman sangat ditentukan oleh hara yang dalam bentuk tersedia dalam kondisi berimbang. Parman (2007) mengemukakan bahwa pupuk organik memiliki sifat yang dapat memperbaiki sturktur, fisik dan kimia tanah

\subsection{Pengaruh Mikoriza Terhadap Serta Hasil Tanaman Melon}

Hasil uji $\mathrm{F}$ pada analisis ragam) menunjukan bahwa hasil analisis infeksi akar akibat pemberian mikoriza berpengaruh sangat nyata. Rata-rata analisis infeksi akar oleh mikoriza akibat pemberian kompos kulit kopi dapat dilihat pada Tabel 9.

Pengaruh Dosis Kompos Limbah Kulit Kopi Dan Fungi Mikoriza Arbuskular Terhadap Hasil Tanaman Melon (Cucumis melo L) Mohammad Ebigail, EritaHayati, Nanda Mayani) Jurnal Ilmiah Mahasiswa Pertanian Unsyiah, Vol. 4, No. 2, Mei 2019: 101-110 
Tabel 2. Rata-rata infeksi akar akibat pemberian mikoriza arbuskular Dosis Mikoriza (g polibag ${ }^{-1}$ ) Infeksi Akar (\%)

\begin{tabular}{cc}
\hline $\mathrm{M}_{0}(0)$ & $30,91 \mathrm{a}$ \\
$\mathrm{M}_{1}(10)$ & $51,91 \mathrm{~b}$ \\
$\mathrm{M}_{2}(15)$ & $56.00 \mathrm{bc}$ \\
$\mathrm{M}_{3}(20)$ & $61,83 \mathrm{c}$ \\
\hline BNT $0.05 \%$ & 6.82 \\
\hline
\end{tabular}

Keterangan : Angka yang diikuti oleh huruf yang sama pada kolom yang sama berbeda tidak nyata pada taraf peluang $5 \%\left(\mathrm{BNT}_{0,05}\right)$.

Tabel 2 menunjukkan bahwa infeksi akar akibat pemberian mikoriza arbuskular dengan infeksi terbaik dijumpai pada dosis $M_{3}\left(20 \mathrm{~g} \mathrm{polibag}^{-1}\right)$ yang berbeda nyata dengan $\mathrm{M}_{0}$ $\left(0 \mathrm{~g} \mathrm{polibag}^{-1}\right), \mathrm{M}_{1}\left(10 \mathrm{~g}\right.$ polibag $\left.^{-1}\right)$ dan $\mathrm{M}_{2}\left(15 \mathrm{~g}\right.$ polibag $\left.^{-1}\right)$ ' sedangkan infeksi akar terendah dijumpai pada dosis $\mathrm{M}_{0}\left(0 \mathrm{~g}_{\text {polibag }}{ }^{-1}\right)$. Hal ini menunjukan bahwa infeksi akar akibat pemberian mikoriza berpengaruh sangat nyata dengan perlakuan terbaik ditunjukan pada perlakuan 20 g polibag $^{-1}$. Pemberian mikoriza pada infeksi akar tergantung pada tanaman yang diberikan walaupun mikoriza tidak memiliki syarat tanaman khusus agar terjadinya infeksi, besar dan rendahnya infeksi juga tidak menjamin pertumbuhan akan baik pula semua tergantung pada kondisi yang dibutuh kan mikoriza yaitu suhu, kadar air, bahan organik, dan ketersedian hara didalam tanah.

Perkembangan dan peran mikoriza terhadaap pertumbuhan tanaman (Mosse, 1981). Residu akar mempengaruhi ekologi cendawan FMA, Perubahan fisiologis pada akar yang bermikoriza dapat mempengaruhi eksudasi akar berupa asamasam organik dan enzim fosfatase. Asam-asam organik bermuatan negatif dapat mengkelat $\mathrm{Al}^{3+}$ dan $\mathrm{Fe}^{3+}$, sehingga hara $\mathrm{P}$ yang terfiksasi oleh kation-kation dapat menyatu didalam tanah lalu diserap , sedangkan enzim fosfatase dapat memacu proses mineralisasi P organik (Dodd et al. 1987; Smith dan Read 1997).

\subsection{Interaksi Akibat Kompos Kulit kopi dan Mikoriza Arbuskular Terhadap Serta Hasil Tanaman Melon}

Hasil uji $\mathrm{f}$ analisis ragam terdapat interaksi yang sangat nyata antara perlakuan kompos limbah kulit kopi dengan mikoriza pada parameter diameter buah, berat buah dan infeksi akar dapat dilihat pada Tabel 3. 
Tabel 3. Rata-rata diameter buah tanaman melon akibat interaksi kompos limbah kulit kopi dan mikoriza arbuskular

\begin{tabular}{|c|c|c|c|c|}
\hline \multirow{2}{*}{$\begin{array}{c}\text { Dosis Kompos } \\
(\mathrm{g} \text { polibag }\end{array}$} & \multicolumn{4}{|c|}{ Dosis Mikoriza $\left(\mathrm{g} \mathrm{polibag}^{-1}\right.$ ) } \\
\hline & $\mathrm{M}_{0}(0)$ & $\mathrm{M}_{1}(10)$ & $\mathrm{M}_{2}(15)$ & $\mathrm{M}_{3}(20)$ \\
\hline \multicolumn{5}{|l|}{ Diameter Buah (Cm) } \\
\hline $\mathrm{K}_{0}(0)$ & $12,69 \mathrm{Aa}$ & 13,06 Aab & 11,94 Aa & $12,10 \mathrm{Aa}$ \\
\hline $\mathrm{K}_{1}(188)$ & $12,85 \mathrm{Aa}$ & $14,17 \mathrm{Ab}$ & $13,23 \mathrm{Aab}$ & $14,12 \mathrm{Ab}$ \\
\hline $\mathrm{K}_{2}(376)$ & $12,95 \mathrm{Aa}$ & $13,74 \mathrm{ABb}$ & $13.44 \mathrm{Abc}$ & $14,81 \mathrm{Bb}$ \\
\hline $\mathrm{K}_{3}(564)$ & $13,22 \mathrm{Aa}$ & $12,26 \mathrm{Aa}$ & $14.65 \mathrm{Bc}$ & $12,74 \mathrm{Aa}$ \\
\hline BNT $0,05 \%$ & \multicolumn{4}{|c|}{1.36} \\
\hline \multicolumn{5}{|l|}{ Berat Buah (kg) } \\
\hline $\mathrm{K}_{0}(0)$ & $1,05 \mathrm{Ba}$ & $1,17 \mathrm{Bab}$ & $0,60 \mathrm{Aa}$ & $0,81 \mathrm{ABa}$ \\
\hline $\mathrm{K}_{1}(188)$ & $1,02 \mathrm{ABa}$ & $1,35 \mathrm{Bb}$ & 0,76 Aab & $0,69 \mathrm{Aa}$ \\
\hline $\mathrm{K}_{2}(376)$ & $1,09 \mathrm{Aa}$ & $1,02 \mathrm{Aab}$ & $1,10 \mathrm{Abc}$ & $1,64 \mathrm{Bb}$ \\
\hline $\mathrm{K}_{3}(564)$ & $0.99 \mathrm{Aa}$ & $0,87 \mathrm{Aa}$ & $1,22 \mathrm{Ac}$ & $0,94 \mathrm{Aa}$ \\
\hline BNT $0,05 \%$ & \multicolumn{4}{|c|}{0.42} \\
\hline \multicolumn{5}{|l|}{ Infeksi Akar (\%) } \\
\hline $\mathrm{K}_{0}(0)$ & $25,67 \mathrm{Aa}$ & $33,00 \mathrm{Aa}$ & $34,00 \mathrm{Aa}$ & $31,67 \mathrm{Aa}$ \\
\hline $\mathrm{K}_{1}(188)$ & $31,33 \mathrm{Aa}$ & $62,00 \mathrm{BCbc}$ & $56,33 \mathrm{Bb}$ & $78,33 \mathrm{Cb}$ \\
\hline $\mathrm{K}_{2}(376)$ & $25,33 \mathrm{Aa}$ & 43,33 Aab & $65,00 \mathrm{Bb}$ & $77,67 \mathrm{Bb}$ \\
\hline $\mathrm{K}_{3}(564)$ & 41,33 Aa & $69,33 \mathrm{Bbc}$ & $68,67 \mathrm{Bb}$ & $59,67 \mathrm{ABb}$ \\
\hline BNT $0,05 \%$ & \multicolumn{4}{|c|}{21,56} \\
\hline
\end{tabular}

Keterangan: Angka-angka yang diikuti oleh huruf yang sama (huruf kapital horizontal, huruf kecil vertikal) menunjukan tidak berbeda nyata pada uji BNT $0,05 \%$

Tabel 10 menunjukkan bahwa, diameter buah melon akibat Kombinasi dari kompos limbah kulit kopi dan mikoriza terbaik dijumpai pada kombinasi dosis $\mathrm{K}_{2} \mathrm{M}_{3}$ (376 g polibag ${ }^{-1}$ dan $20 \mathrm{~g}$ polibag $\left.^{-1}\right)$ sedangkan kombinasi terendah dijumpai pada dosis $\mathrm{K}_{0} \mathrm{M}_{2}\left(0 \mathrm{~g}\right.$ polibag $^{-1}$ dan $\left.15 \mathrm{~g} \mathrm{polibag}^{-1}\right)$. Kombinasi dari kompos limbah kulit kopi dan mikoriza arbuskular terbaik dijumpai pada perlakuan $\mathrm{K}_{2} \mathrm{M}_{3}\left(376 \mathrm{~g}_{\text {polibag }}{ }^{-1}\right.$ dan $\left.20 \mathrm{~g} \mathrm{polibag}^{-1}\right)$ yang berbeda tidak nyata dengan kombinasi perlakuan $\mathrm{K}_{1} \mathrm{M}_{1}\left(188 \mathrm{~g}_{\text {polibag }}{ }^{-1}\right.$ dan $10 \mathrm{~g}$ polibag $\left.{ }^{-1}\right)$. Kombinasi dari kompos limbah kulit kopi dan mikoriza arbuskular terendah dijumpai pada perlakuan $\mathrm{K}_{0} \mathrm{M}_{2}(0$ $\mathrm{g}_{\text {polibag }}{ }^{-1}$ dan $\left.15 \mathrm{~g}_{\text {polibag }}{ }^{-1}\right)$. Kombinasi dari kompos limbah kulit kopi dan mikoriza arbuskular terbaik dijumpai pada perlakuan $\mathrm{K}_{1} \mathrm{M}_{3}\left(188 \mathrm{~g}_{\text {polibag }}{ }^{-1} \mathrm{dan} 20 \mathrm{~g}_{\text {polibag }}{ }^{-1}\right)$ sedangkan kombinasi terendah dijumpai $\mathrm{K}_{0} \mathrm{M}_{0}\left(0 \mathrm{~g}\right.$ polibag $\left.^{-1} \mathrm{dan}_{0} \mathrm{~g}_{\text {polibag }}{ }^{-1}\right)$. Penelitian ini menunjukkan bahwa pemberian kompos kulit buah kopi $\mathrm{K}_{3}\left(564 \mathrm{~g}_{\text {polibag }}{ }^{-1}\right)$ dan mikoriza $\mathrm{M}_{2}$ $\left(15 \mathrm{~g} \mathrm{polibag}^{-1}\right)$ berpengaruh sangat nyata terhadap diameter buah, hal ini diduga karena kompos dapat dikirim oleh akar kepada tanaman dengan baik sehinggga meningkatkan penyerapan unsur hara yang diperlukan oleh tanaman. Dalam pembentukan buah unsur hara $\mathrm{P}$ sangat diperlukan meskipun $\mathrm{P}$ terikat lebih banyak dibanyak dibandingkan $\mathrm{P}$ tersedia hal ini sesuai dengan pernyataan Rinsema (1986) unsur P berguna dalam merangsang tumbuhnya akar dan berperan dalam pembentukan protein sehingga buah dapat membentuk dengan optimum

Unsur fosfor dibutuhkan sebagai pengiriman energy sehingga dapat memperlancar proses alokasi energi guna metabolisme pada tanaman dapat berfungsi dengan baik sehingga produksi julmlah buah dan berat buah menjadi meningkat. Ircham Riyadi, 2014). Penelitian Budiman (2004) menyatakan bahwa dengan tersedianya hara yang optimal cukup pada fase

Pengaruh Dosis Kompos Limbah Kulit Kopi Dan Fungi Mikoriza Arbuskular Terhadap Hasil Tanaman Melon (Cucumis melo L) Mohammad Ebigail, EritaHayati, Nanda Mayani) Jurnal Ilmiah Mahasiswa Pertanian Unsyiah, Vol. 4, No. 2, Mei 2019: 101-110 
pertumbuhan menyebabkan metabolisme pada tanaman akan lebih aktif yang mengakibatkan proses pemanjangan pembelahan dan differensiasi sel akan lebih optimal sehingga pembentukan buah akan menjadi lebih maksimal. Menurut Kastono (2005) peningkatan bahan organik, bahan anorganik, dan air akibat perluasan area penyerapan akar akan meningkatkan pertumbuhan vegetatif tanaman serta berpengaruh terhadap hasil tanaman ketersedian unsur hara $\mathrm{P}$ mengakibatkan fotosintat yang dialokasikan menjadi besar yang mengakibatkan pembentukan buah menjadi lebih besar dengan adanya peran mikoriza, penelitian purba (2005) mengungkapkan manfaat dari mikoriza dengan tanaman yaitu dapat menunjang serapan hara fosfor dan dapatmemulihkan tanaman, selain itu mikoriza juga dapat membantu perbaikan nutrisi tanaman sehingga tanaman dapat memberikan hasil yang baik

Pada berat buah melon terdapat interaksi yang berpengaruh sangat nyata akibat pemberian kompos limbah kulit kopi dan mikoriza arbuskularpada dosis kompos $\mathrm{K}_{3}(564 \mathrm{~g}$ polibag $\left.^{-1}\right)$ dan mikoriza dosis $\mathrm{M}_{3}\left(20 \mathrm{~g}_{\text {polibag }}{ }^{-1}\right)$ hal ini dikarenakan pemberian kompos dapat memberikan unsur hara yang baik bukan hanya pada tanaman namun juga pada media tanam dalam hal ini ialah tanah sehingga pertumbuhan dan produktivitas tanaman lebih baik, pernyataan ini senada dengan lingga (2005) mengungkapkan pupuk organik murni walaupun dalam jumlah yang sedikit tetapi dapat memberikan pengaruh yang sangat signifikan pada tanah yang bermanfaat dalam meningkatkan produktivitas, mempercepat proses panen, merangsar tumbuhnya akar, batang, bunga dan daun

Selain itu pemberian mikoriza juga berperan dalam penyerapan unsur hara dalam kondsi yang terikat khususnya $\mathrm{P}$ dimana unsur $\mathrm{P}$ ini berperan dalam pembentukan buah pernyataan ini didukung oleh Rosliani (2006) pemberian mikoriza yang menyebabkan ketersedian unsur hara yang awalnya terikat menjadi tersedia lebih banyak didalam tanah sehinnga akar pada tanaman mampu menyerap unsur hara yang lebih optimum dengan bantuan hifa hifa pada mikoriza yang selanjutnya diserap oleh tanaman sehingga dapat menstimulir terbentuknya buah dimana dapat mendorong terbentuknya buah yang lebih besar dan lebih berat. Kemudian interaksi pada infeksi akar tanaman melon dijumpai pada perlakuan dosis kompos $\mathrm{K}_{1}\left(188 \mathrm{~g}\right.$ polibag $\left.^{-1}\right)$ dan dosis mikoriza $\mathrm{M}_{3}\left(20 \mathrm{~g} \mathrm{polibag}^{-1}\right)$ hal ini diduga karena mikoriza menjadikan kompos sebagai sumber unsur hara dimana mikoriza membantu akar pada proses penyerapan hara yang ada pada kompos. Hal yang sama juga disampaikan Purba (2005) manfaat yang utama antara simbiosis pada mikoriza dan tanaman adalah serapan unsure hara yang lebih optimal dan memperbaiki pertmubuhan pada tanaman. Kompos merupakan sumber makanan bagi tanaman yang masuk melalui akar sehingga terjadi interaksi ketika pemberian kompos dan mikoriza diberikan hal ini juga diungkapkan oleh Smith (1997) bahwasanya mikoriza menyediakan hara yang diperlukan tanaman melewati infeksi dan kolonisasi didalam akar tanaman

\section{SIMPULAN DAN SARAN}

Penggunaan dari kompos limbah kulit kopi berpengaruh sangat nyata. Terhadap diameter buah dan berpengaruh sangat nyata berat buah. Dosis kompos terbaik dijumpai pada perlakuan $\mathrm{K}_{2}$ (376 $\left.\mathrm{g}_{\text {polibag }}{ }^{-1}\right)$. Terdapat kombinasi sangat nyata akibat penggunaan kompos limbah kulit kopi terahadapdiameter buah dan berat buah, interaksi terbaik dijumpai pada perlakuan $\mathrm{K}_{2} \mathrm{M}_{3}\left(376 \mathrm{~g}_{\text {polibag }}{ }^{-1}\right.$ dan $20 \mathrm{~g}$ polibag ${ }^{-1}$ ) dan interaksi infeksi akar pada $\mathrm{K}_{1} \mathrm{M}_{3}(188$ $\mathrm{g} \mathrm{polibag}^{-1}$ dan $\left.20 \mathrm{~g} \mathrm{polibag}^{-1}\right)$. Perlu adanya studi lebih lanjut untuk menguji manfaat kompos dan keaktifan mikoriza dalam meningkatkan pertumbuhan tanaman melon dengan melihat jenis mikoriza serta melibatkan beberapa varietas melon.

Pengaruh Dosis Kompos Limbah Kulit Kopi Dan Fungi Mikoriza Arbuskular Terhadap Hasil Tanaman Melon (Cucumis melo L) Mohammad Ebigail, EritaHayati, Nanda Mayani) Jurnal Ilmiah Mahasiswa Pertanian Unsyiah, Vol. 4, No. 2, Mei 2019: 101-110 


\section{DAFTAR PUSTAKA}

Arfah, C. Z., H, Fuadi dan R. Marai. 2014. Pengaruh media tanam dan konsentrasi zat pengatur tumbuh dekamon 22.431 pada pertumbuhan dan hasil tanaman melon (Cucumismelo L.). J.Kawista. 1(1): 10-14.

Badan Pusat Statistik Indonesia. 2016. Produksi Sayuran di Indonesia 2015-2016. https://www.bps.go.id

Berlian, Z., Syarifahdan S. S Devi. 2015. Pengaruhpemberianlimbahkulit kopi (coffe arobusta 1.) terhadap pertumbuhan cabai keriting (capsicum annum 1.). J. Biota. 1(1): 22-31.

Budiman, A. 2001. Pertumbuhan Tanaman gambir (Uncaria Gambir ROXB) Pada Beberapa Dosis FMA. Skripsi. Fakultas Pertanian Universitas Andalas, Padang

Dasgan, H. Y., S. Kusvurandan I. Ortas. 2008. Responses of soilless grown tomato plants to arbuscular mycorrhizal fungal (Glomusfasciculatum) colonization in re-cycling and open systems. African Journal of Biotechnology 7(20): 3606-3613.

Dodd, J. C.,C. C Burto,R. G BurnsdanP. Jeffries. 1987. Phosphatase activity associated with the roots and the rhizosphere of plants infected with vesicular arbuscular mycorhizal fungi. New Phytologist 107: 163-172.

Dwijoseputro, D. 1983. Pengantar Fisiologi Tumbuhan. PT. Gramedia, Jakarta. 232 hlm.

Hayati, E., T. Mahmud dan R. Fazil. 2012. Pengaruh jenis pupuk organic dan varietas terhadap pertumbuhan dan hasil tanaman cabai (capsicum annum L.). J. Floratek. 7:173-181.

Huang, Z., Z. Zou, C. He, Z. He, Z. Zhang dan J. Li. 2011. Physiological and photosynthetic responses of melon (Cucumis melo L.) seedlings to three Glomus species under water deficit. Plant and Soil 339: 391-399.

Ircham, R., P. Bambang dan Pardono. 2014. Pemanfaatan limbah tepung aren dan mikroorganisme lokal untuk meningkatkan hasil tanaman cabai merah besar (capsicum annum 1.). J. El Vivo. 2:(2)34-41.

Jeffries P, Gianinazzi S, Perotto S, Turnau K dan Barea J. 2003. The contribution of arbuscular mycorrhizal fungi in sustainable maintenance of plant health and soil fertility. Biology and Fertility of Soils 37: 1-16.

Kastono, D. 2005. Tanggapan pertumbuhan dan hasil kedelai hitam terhadap penggunaan pupuk organik dan biopestisida gulma siam (chromolaena odorata) respons on growth and yield of black soybean in usage of organic fertilizer and biopesticide of siam weed (chromolaena odorata). J. Ilmu Pertanian. 12:(12)103-116.

Lingga, P dan Marsono. 2005. Petunjuk Penggunaan Pupuk. Penebar Swadaya, Jakarta.

Mosse, S. 1981. Vesicular Arbuscular Mycorizarescarh For Tropical Agriculture. Ress. Bull 
Purba, T. 2005. Isolasi dan uji efektifitas jenis MVA terhadap pertumbuhan bibit kelapa sawit (Elais guineensis) pada tanah Histosol dan Ultisol. Pascasarjana Universitas Sumatera Utara, Medan.

Puslitkoka, 2005. Panduan Lengkap Budidaya Kakao. Agromedia Pustaka, Jakarta.

Rinsema, W. J. 1986. Pupuk dan Cara Pemupukan. Bhratara Karya Aksara, Jakarta.

Rosliani, R., Y. Hilman, dan N. Sumarni. 2006. Pemupukan fosfat alam, pupuk kandang domba, dan inokulasi cendawan mikoriza arbuskula terhadap pertumbuhan dan hasil tanaman mentimun pada tanah masam. J. Hortikultura. 16(1):21-33.

Rosmarkan, A. dan N.W. Yuwono. 2002. Ilmu Kesuburan Tanah. Kanisius, Yogyakarta. p. 224.

Safuan, L. O danA. Bahrun. Pengaruh bahan organik dan pupuk kalium terhadap pertumbuhan dan produksi tanaman melon (Cucumis melo L.) Effect of Organic Materials and Potassium Fertilizers on Growth and Production Plant Melon (Cucumis melo L.). J. Agroteknos. 2(2):69-76.

Srivastava, N. K., D. K Srivastavadan P. Singh. 2012. A preliminary survey of the vesicular arbuscular mycorrhizal status of vegetable and fruit yielding plants in Eastern U.P. Indian Journal of Land dan Sciences 1(2): 79-82.

Smith, J. L., Papendick, D. F. Bezdicek, dan J. M. Lynch, 1993. Soil organic matter dynamics and crop residue management. p: 65-94. in : Metting, F. B. (ed.). Soil Microbial Ecology. Marcel Dekker, Inc. New York Barsel-Hongkong.

Sudiarto dan Gusmaini. 2004. Peran bahan organik in situ untuk efisiensi budidaya tanaman perkebunan yang berkelanjutan. Jurnal Litbang Pertanian.Vol 23(2). 45 hlm.

Sunardjono, H. 2005. Bertanam 30 Sayuran. Penebar Swadaya. Jakarta.

Tetelepta, L. D. 2014. Pemacuan pertumbuhan melon (Cucumismelo 1.) dengan menggunakan cendawan mikoriza arbuskula dan bakteri Azospirillum Sp. Skripsi. Institut Pertanian Bogor, Bogor.

Valentiah, F. E., L. Endang dan P. Sugeng. 2015. Aplikasi kompos kulit kopi untuk perbaikan sifat Kimia dan fisika tanah inceptisolserta Meningkatkan produksi brokoli. J.Tanah dan Sumberdaya Lahan 2(1):147-154 